Reprod. Nutr. Dévelop. 1980, 20 (4 A), 1041-1050.

\title{
Profiles of plasma gonadotropin and $17 \beta$-estradiol in the common carp, Cyprinus carpio L., as related to spawning induced by hypophysation or LH-RH treatment
}

\author{
par Claudine WEIL, A. FOSTIER *, L. HORVATH **, Sylviane MARLOT *, \\ M. BERSCENYI ** \\ Laboratoire de Physiologie des Poissons, I.N.R.A., \\ 78350 jouy-en-Josas, France. \\ * Laboratoire de Physiologie des Poissons, I.N.R.A., \\ Campus Rennes-Beaulieu, 35031 Rennes Cedex, France. \\ ** Warm Water Fish Hatchery, Szazhalombatta, Hungary.
}

Summary. Plasma gonadotropin (GTH) and $17 \beta$-estradiol $\left(17 \beta-E_{2}\right)$ levels and oocyte stage have been studied in the common carp, Cypinus carpio L., after classical « hypophysation » (two intraperitoneal pituitary injections of $0.3 \mathrm{mg} / \mathrm{kg}$ and $2.7 \mathrm{mg} / \mathrm{kg}$ at a 12 -hr inter$\mathrm{val}$ ) or $\mathrm{LH}-\mathrm{RH}$ treatment (two intracardiac injections of $3 \mathrm{\mu g} / \mathrm{kg}$ at a $3-\mathrm{hr}$ interval). After the first pituitary injection of LH-RH treatment, GTH increase was followed by a significant increase of $17 \beta-E_{2} 7 \mathrm{hrs}$ after the injection. The higher GTH levels after the second pituitary injection did not increase that secretion. After classical « hypophysation », one-half of the females ovulated. There was no difference between spawning and non-spawning fishes in relation to hormonal paramefers. LH-RH treatment only induced a shifting of the nucleus.

\section{Introduction.}

Few results are available on endocrine compounds in carp during the last stages of the reproductive cycle and ovulation. At ovulation time, gonadotropin (GTH) levels are high (Billard ef al., 1978 ; The Fish reproductive Physiology Research Group ef al., 1978) and estrogen levels are low (Eleftheriou, Norman and Summerfelt, 1968).

In temperate climates, carp spawning is usually initiated by injections of crude pituitary extracts. The most empirically efficient procedure is to give two injections, the first containing 10 p. 100 of the total dose and the second 90 p. 100 (Antalfi and Tölg, 1975). This classical so-called « hypophysation » has been tentatively replaced by LH-RH injections which induce ovarian maturation (Sokolowska, Popek and Bieniarz, 1978), or even ovulation (Conference on Application of Hormones to Economic Fish, 1975), in carp and ovulation in the ayu (Hirose and Ishida, 1974), goldfish (Lam ef al., 1975, 1976), plaice and goby (Aida et al., 1978). Using these methods, 
10 to 60 p. 100 of non-spawning females can generally be observed in a stock. Incomplete vitellogenesis could explain these results, the oocytes and/or follicles not being ready to ovulate. Moreover, vitellogenic estrogens could have a negative effect on gonadotropic secretion and even a direct negative effect on the ovary, as reported in vitro in trout by Jalabert (1975). Thus, the variability of the ovarian capacity to secrete estradiol after « hypophysation 》 of LH-RH treatment might express the variability in the spawning response.

LH-RH is able to stimulate gonadotropic hormone production in cyprinids (Breton and Weil, 1973 ; Weil, Breton and Reinaud, 1975 ; Crim, Peter and Billard, 1976) and salmonids (Crim and Cluett, 1974 ; Weil et al., 1978). Exogenous gonadotropin injections increase estradiol production during vitellogenesis in trout (Billard et al., 1978) and at the end of the cycle in carp (Fostier, Breton and Jalabert, 1979), but at that final stage in trout, Van Bohemen and Lambert (1979) did not detect aromatization enzymes in the ovary. In the dog-fish, an anti-gonadotropic serum has no effect on the plasma estradiol concentration (Sumpter et al., 1978). Initiating filapia spawning with warm water stimulates androgen and corticosteroid production but not that of estradiol (Katz and Eckstein, 1974). In carp, Horvath et al. (1978) could not determine the action of « hypophysation » on plasma estradiol levels, perhaps because of the high variability between the fish and the small size of the lots.

To confirm our previous results after using « hypophysation » to stimulate estradiol secretion in carp (Fostier, Breton and Jalabert, 1979), we repeated the same type of experiment using two different carp strains and analyzing the relations between the spawning response and the estradiol secretion. More accurate profiles of c-GTH and estradiol were obtained during the first 12 hours after the injection of a lower dose of pituitary extract or after the stimulation of endogenous gonadotropic production by $\mathrm{LH}-\mathrm{RH}$ treatment. We used relatively low gonadotropin levels, only stimulating oocyte maturation but not ovulation. The actual safest LH-RH spawning treatment is LH-RH " priming », then an injection of pituitary extract 12 or 24 hrs later, according to the water temperature. The efficiency of the " priming 》 can be estimated by the stage of oocyte maturation reached before the second injection (Jalabert et al., 1977).

In the present work, we have tried for the first time in fish to evaluate the time-lag of steroidogenic response after an experimental increase of the gonadotropin levels.

\section{Material and methods.}

Animals. - The experimenis were conducted in May at the Warm Water Fish Hatchery in Szazhalombatta, Hungary. Two different carp strains ( $S$ and $Z$ ) were used. Before the experiment, females weighing 5 to $8 \mathrm{~kg}$ were kept outdoors in concrete tanks at $18^{\circ} \mathrm{C}$ then transferred into raceways in the hatchery.

Classical « hypophysation » was performed at $22^{\circ} \mathrm{C}$. Total pituitary extracts were prepared in saline $(3 \mathrm{mg} / \mathrm{ml})$ from pituitary dried in acetone. A total dose of $3 \mathrm{mg}$ per $\mathrm{kg}$ of body weight was injected intraperitoneally. A first injection, given at the onset of the experiment, included 10 p. 100 of the total dose ; the second one, given $12 \mathrm{hrs}$ later, contained the remaining 90 p. 100 . Hypophysations were repeated five times with 5 to 10 fish. 
LH-RH treatment. - Intracardiac injections of LH-RH $(3 \mu \mathrm{g} / \mathrm{kg}$ of body weight) (Hoescht OP-97) were given at the onset of the experiment and 3 hrs later. The experiment was performed at $22^{\circ} \mathrm{C}$ with a group of $5 \mathrm{Z}$-strain carp.

Samples. - The fish were anesthetized with MS 222 (1/10 000). The blood was then sampled and the oocyte stages determined, as previously described by Jalabert ef al. (1977).

Hormone measurement. - Gonadotropin (c-GTH) was measured by a double radioimmunoassay using a pure gonadotropin, as described by Breton, Kann and BurzawaGérard (1971). An antibody raised against this pure c-GTH was used at a dilution of $1 / 5 \cdot 10^{-5}$.

Plasma $17 \beta$-estradiol levels were determined by a double radio immunoassay after LH-20 chromatography discarding the " estrone fraction 》, as described by Fostier ef al. (1978). The antibody used, a gift from M. Terqui (Dray et al., 1971), binds estradiol (100 p. 100), some estrone (11 p. 100), 16-ketoestradiol ( 9 p. 100) and epiestriol ( 8 p. 100) but no $17 \alpha$-estradiol, estriol, 2 -methoxyestrone, testosterone, 11-keto-

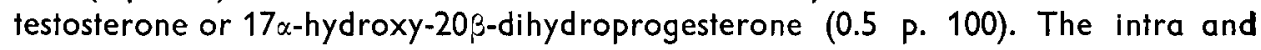
inter-assay coefficients of variation were 4 and 15 p. 100, respectively.

Statistical methods. - The mean of the independent samples was compared by the Mann-Whitney U-test (non-parametric method).

In a paired comparison, the significance of the mean differences was tested by Student's t-test.

The percentages were compared using the $\chi^{2}$ test.

\section{Results.}

Classical «hypophysation ».

a) Hormone levels. Before injection, the GTH $(P<0.001)$ and $E_{2}(P<0.025)$ levels of the two carp strains were different. They were low before spawning initiation, and no correlation was found between the two (table 1). Twelve hours after the first injection, an increase of the $17 \beta-E_{2}$ levels corresponded to the high quantities of exogenous GTH found in the plasma, but those levels did not increase after the second

TABLE 1

Plasma gonadotropin and $17 \beta$-estradiol levels in carp before spawning induction

\begin{tabular}{llllllll}
\hline \multirow{2}{*}{ Strain } & \multicolumn{2}{c}{$\mathrm{c}-\mathrm{GTH} \mathrm{ng} / \mathrm{ml}$} & \multicolumn{3}{c}{$17 \beta-\mathrm{E}_{2} \mathrm{ng} / \mathrm{ml}$} \\
\cline { 2 - 8 } & $\mathrm{n}$ & mean & $\mathrm{SD}$ & $\mathrm{n}$ & mean & $\mathrm{SD}$ \\
\hline $\mathrm{S} \ldots \ldots \ldots$ & 33 & 3.76 & 1.56 & 32 & 1.02 & 0.64 \\
\hline $\mathrm{Z} \ldots \ldots \ldots \ldots$ & 37 & 6.36 & 3.11 & 38 & 1.50 & 1.04
\end{tabular}


injection which gave higher GTH levels (fig. 1). The same hormonal pattern was obtained in both strains. The individual values showed no significant correlation between the two hormones at 12 and 24 hrs. Response sensitivity in each fish was evaluated using the ratio :

$$
\frac{\text { estimated surface of } E_{2} \text { secretion between } 0 \text { and } 12 \mathrm{hrs}}{\text { estimated surface of GTH secretion between } 0 \text { and } 12 \mathrm{hrs}} \text {. }
$$

No difference in sensitivity was detected between the two strains.

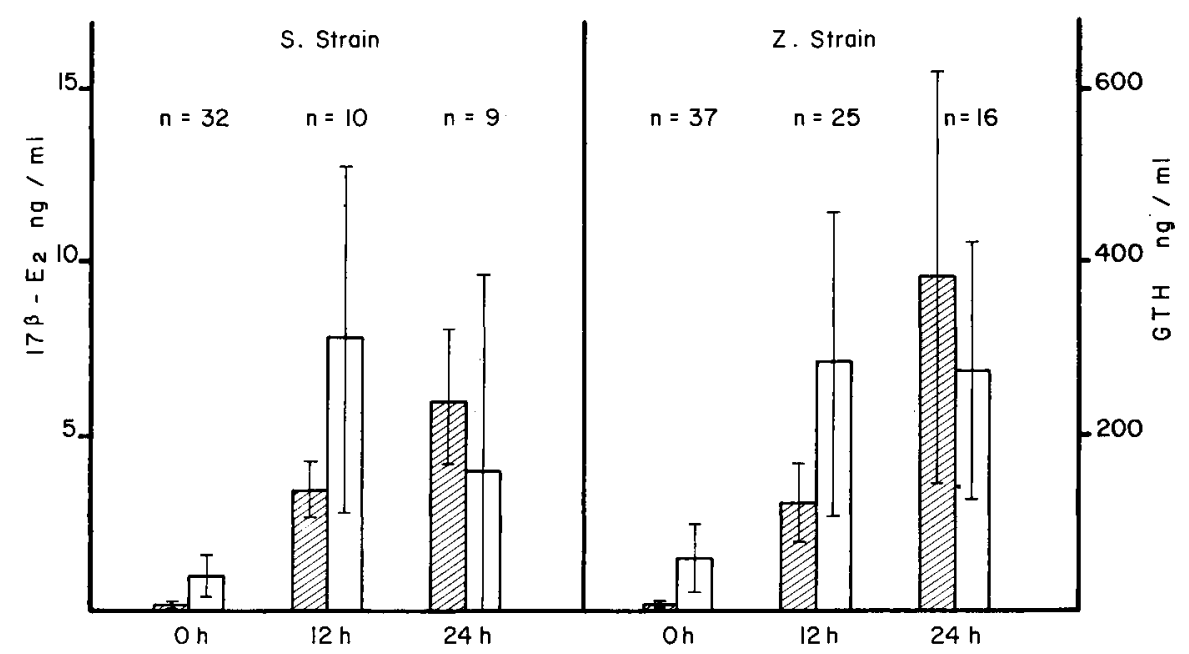

FIG. 1. - GTH (hatched bars) and $17 \beta-E_{2}$ (open bars) profiles in two strains of carp plasma during classical "hypophysation " of $22{ }^{\circ} \mathrm{C}$. First injection at $0 \mathrm{hr}: 0.3 \mathrm{mg}$ pituitary $/ \mathrm{kg}$ body weight; second injection at $12 \mathrm{hrs}: 2.7 \mathrm{mg}$ pituitary $/ \mathrm{kg}$ body weight. Blood samples were taken at 0,12 and 24 hrs. $n=$ number of observations. Means \pm standard deviation.

b) Spawning. One-half of the group of females $(n=21)$, monitored for spawning, ovulated. We observed no qualitative difference in this respect between the two strains, and no differences could be found between the group of spawning females $(n=11)$ and the non-spawning one $(n=10)$, either in relation to the total exogenous GTH injected, the sensitivity of the response as described above, or the GTH and the $17 \beta-E_{2}$ at $0 \mathrm{hr}$.

Profiles of plasma $17 \beta$-estradiol and c-GTH and oocyfe stages after one pituitary injection or $\mathrm{LH}-\mathrm{RH}$ treatment.

a) Hormone levels with pifuitary extract injection. GTH and $17 \beta-\mathrm{E}_{2}$ levels were monitored in blood samples taken every $2 \mathrm{hrs}$ during $12 \mathrm{hrs}$, in 5 females of the Zstrain, after the injection of $0.3 \mathrm{mg}$ of pituitary extract for $1 \mathrm{~kg}$ of body weight (fig. 2). That dose was equivalent to the first injection of a classical « hypophysation 》 or socalled « priming».

One hour after the injection, the c-GTH level increased in all the females $(P<0.05)$ as compared to the basic level $(5.42 \pm 1.36 \mathrm{ng} / \mathrm{ml})$. This level continued to 
rise for 3 hrs $(P<0.001)$ and then remained high during the next $12 \mathrm{hrs}$. On the other hand, $17 \beta-E_{2}$ was low during the first $3 \mathrm{hrs}$, began to increase in four females $5 \mathrm{hrs}$ after the injection, and reached a significantly higher level $(P<0.05)$ than the basic one $(3.0) \pm 1.7 \mathrm{ng} / \mathrm{ml}) 7 \mathrm{hrs}$ after the injection. Its maximal value was attained $12 \mathrm{hrs}$ later in all the fish.

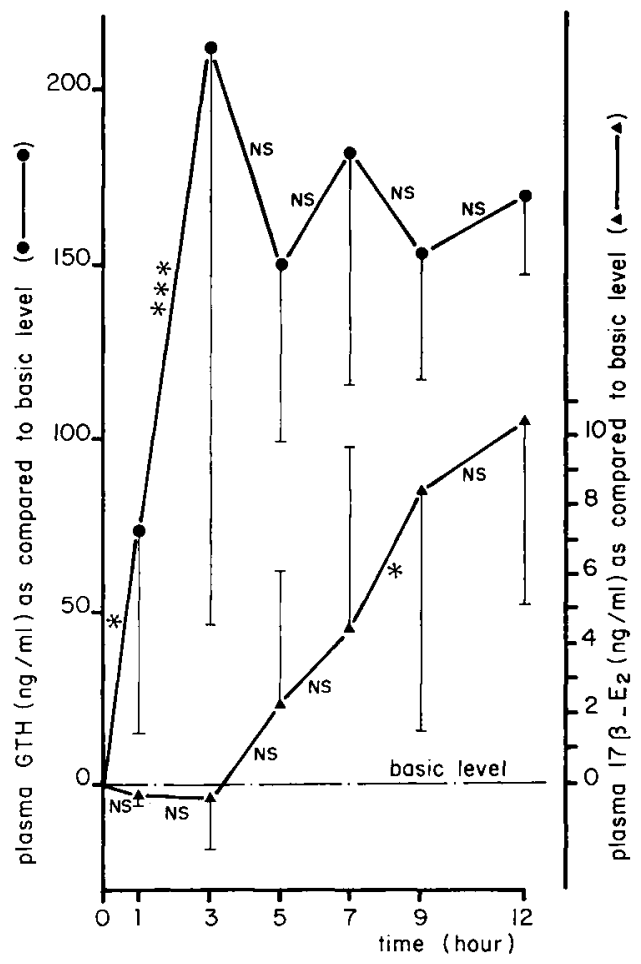

FIG. 2. - Plosma GTH and 17 $\beta-E_{2}$ profiles during $12 \mathrm{hrs}$ ofter the first injection of classical «hypophysation 》 in $5 \mathrm{Z}$-strain carp. Injection of $0.3 \mathrm{mg}$ pituitary $/ \mathrm{kg}$ body weight at $0 \mathrm{hr}$. Blood samples were taken at $0,1,3,5,7,9$, and $12 \mathrm{hrs}$. Basic level : $\mathrm{GTH}$ and $17 \beta-\mathrm{E}_{2}$ levels at $0 \mathrm{hr}$. Each point represents the mean, the vertical lines the standard deviations. Differences between values are expressed as :

$$
\text { NS }=\text { non-significant, } * P<0.05, * * P<0.01, * * * P<0.005 .
$$

b) Hormone levels with $\mathrm{LH}-\mathrm{RH}$ treatment. $\mathrm{c}-\mathrm{GTH}$ and $17 \beta-\mathrm{E}_{2}$ profiles were monitored for $12 \mathrm{hrs}$ in $5 \mathrm{Z}$-strain females after LH-RH treatment (fig. 3). The level of c-GTH, observed $30 \mathrm{~min}$ after the first injection, increased $(P<0.05)$ in all the females, as compared to the basic level $(5.42 \pm 1.36 \mathrm{ng} / \mathrm{ml})$. The second injection also stimulated c-GTH secretion since the values at $31 / 2 \mathrm{hrs}$ were higher than those at $3 \mathrm{hrs}$.

Between 5 and $7 \mathrm{hrs}$, the c-GTH level decreased significantly $(P<0.05)$, and until $12 \mathrm{hrs}$ was identical to the level at $3 \mathrm{hrs}$, just before the second injection. On the other hand, the $17 \beta-E_{2}$ level was low and steady during the first 5 hrs; it then increased significantly $(P<0.05)$ between 5 and $7 \mathrm{hrs}$ in 4 females to reach a value higher 
$(P<0.05)$ than the basiclevel $(1.70 \pm 1.22 \mathrm{ng} / \mathrm{ml})$. During the next $12 \mathrm{hrs}$, it continued to augment $(P<0.05)$ in 4 of the females, while the fifth female snowed a slower increase.

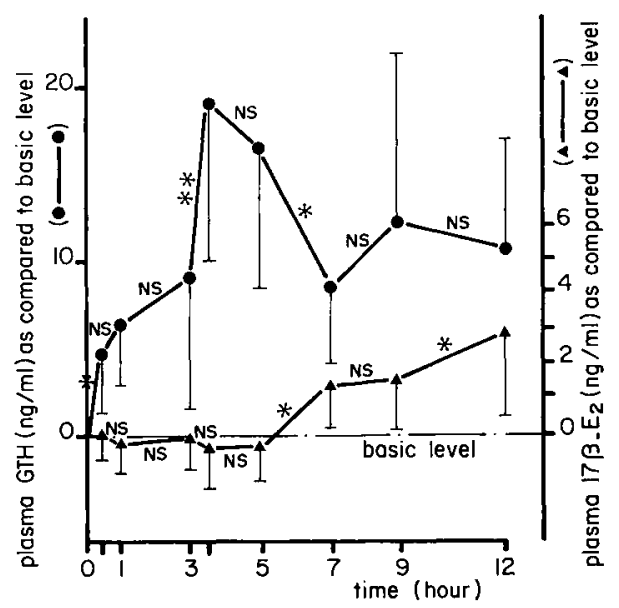

FIG. 3. - Plasma GTH and $17 \beta-E_{2}$ profiles after two injections of $L H-R H(3 \mu \mathrm{g} / \mathrm{kg}$ body weight $)$ in 5 female $Z$-strain carp. First injection at $0 \mathrm{hr}$, second injection $3 \mathrm{hrs}$ later. Blood samples were taken at $0,1 / 2,1,3,31 / 2,5,7,9$ and $12 \mathrm{hrs}$. Basic level : GTH and 17/- $\mathrm{E}_{2}$ levels at $0 \mathrm{hr}$. Each point represents the mean, the vertical lines the standard deviations. Differences, between values are expressed as : NS $=$ non-significant, $* \mathrm{P}<0.05, * * \mathrm{P}<0.01, * * * \mathrm{P}<0.005$.

During those $12 \mathrm{hrs}$ of sampling, the amount of circulating c-GTH was lower than that obtained after pituitary injection $(P<0.001)$. The estradiol levels with the two treatments only differed at $12 \mathrm{hrs}$, the observed value being higher after pituitary injection $(P<0.02)$.

Oocyte stages. - No spawning was noted $12 \mathrm{hrs}$ after pituitary injection or LH-RH treatment, but the nucleus shiffed towards the periphery (table 2). Before either treat-

TABLE 2

Percentage of eggs at different stages

\begin{tabular}{|c|c|c|c|c|}
\hline & Stage 1 & Stage 2 & Stage 3 & Stage 4 \\
\hline $\begin{array}{l}\text { Before pituitary injection } \ldots \ldots \ldots \ldots \ldots \ldots \ldots \ldots \\
12 \mathrm{hrs} \text { after pituitary injection } \ldots \ldots \ldots \ldots \ldots \ldots \ldots \\
\text { Before } \mathrm{LH} / \mathrm{RH} \text { treatment } \ldots \ldots \ldots \ldots \ldots \ldots \ldots \ldots \\
12 \mathrm{hrs} \text { after } \mathrm{LH}-\mathrm{RH} \text { treatment } \ldots \ldots \ldots \ldots \ldots \ldots \ldots\end{array}$ & $\begin{array}{r}37.5 \\
0 \\
24.4 \\
0.8\end{array}$ & $\begin{array}{c}58.8 \\
0 \\
72.8 \\
0\end{array}$ & $\begin{array}{r}1.8 \\
35.4 \\
2.4 \\
75.6\end{array}$ & $\begin{array}{r}1.9 \\
64.6 \\
0.4 \\
23.6\end{array}$ \\
\hline
\end{tabular}

Stage $1:$ nucleus at the center of the oocyte.

Stage 2 : nucleus starts peripheral migration but is still less than half way to the periphery.

Stage 3 : nucleus more than half way to the periphery.

Stage 4 : nucleus situated close to the micropyle. 
ment, all the nuclei were at the center of the oocyte (stage 1) or starting peripheral migration (stage 2). Twelve hours later, all the nuclei had passed the middle of the oocyte radius (stage 3 ) or were near the micropyle (stage 4).

\section{Discussion.}

Estradiol and gonadotropin levels, though significantly different in the two strains analyzed, were low before spawning induction in both lots, when exogenous vitellogenesis seemed to be morphologically over. Higher levels were reported for $17 \beta-E_{2}$ by Eleftheriou et al. (1968) using a fluorescence assay and for estrogens by Horvath ef al. (1978) using a gas chromatographic method. Higher estrogen values were also observed by Schreck and Hopwood (1974) using radioimmunoassay in another cyprinid, the goldfish, but the spawning time was not accurately recorded. According to the assay specificities claimed by those authors, the difference with our results may be related to the presence of estrone, which did not interfere with our assay. Different environmental conditions may also explain such results (Billard et al., 1978).

The levels of exogenous c-GTH found after « hypophysation » were in the same range as those reported in other similar experiments (Jalabert ef al., 1977 ; Fostier, Breton and Jalabert, 1979 ; Bieniarz ef al., 1980). Steroidogenic structures can respond to c-GTH increase earlier, as observed by Fostier, Breton and Jalabert (1979). However, the stimulation is limited since the second pituitary injection did not increase the mean estradiol level. Furthermore, 19 fish out of 25 had lower $E_{2}$ levels 12 hrs after the second injection than they did $12 \mathrm{hrs}$ after the first one. As total extracts were used, we could not determine whether the steroidogenic potentialities were exhausted or if an inhibitory factor was present.

After hypophysation, $E_{2}$ secretion was detected in all the females but no relation could be established between the estrogenic response and the spawning ability of an individual. However, during a natural cycle, the detected peaks of estradiol appeared during vifellogenesis and not during the spawning season when the c-GTH peaks were detected (Billard et al., 1978). But we have no data on the period just before and after ovulation in natural conditions.

The LH-RH treatment we used ( 2 injections of $3 \mathrm{mg} / \mathrm{kg}$ at a $3-\mathrm{hr}$ interval) induced oocyte maturation but nof ovulation. Other authors (Sokolowska ef al., 1978), using doses of the same order $(1 \mathrm{mg} / \mathrm{kg} /$ day for 9 days), also obtained more rapid oocyte maturation but not ovulation. Giving doses 600 to 1500 times higher than ours induced ovulation in the ayu (Hirose and Hishida, 1974), the goldfish (Lam ef al., 1975, 1976), different species of carp (Conference on Application of Hormones to economic Fish, 1975), the Japanese medaka (Chan, 1977), the plaice and the goby (Aida ef al., 1978).

In vivo LH-RH stimulation of C-GTH has been previously demonstrated (Breton and Weil, 1973) to vary with animal maturity (Weil, Breton and Reinaud, 1975). For the first time, the present study reports steroidogenic stimulation in fish after LH-RH injection, although it has been shown in reptiles (Callard and Lance, 1977) and birds Sterling, Lea and Sharp, 1978). 
The level of c-GTH, after only one injection of a relatively low dose of pituitary extract, remained high without significantly decreasing from $3 \mathrm{hrs}$ to the end of sampling. That level was in the same range as the ovulatory surge in goldfish (Stacey, Cook and Peter, 1979), but the injection alone did not induce ovulation. The LH-RH treatment in our conditions induced lower c-GTH levels, but the main peak lasted about the same time ( 2 hrs) as the ovulatory surge in goldfish (Stacey, Cook and Peter, 1979). In our study, the total amount of c-GTH in the blood for 12 hrs after such a stimulation was 15 times lower than that caused by the first hypophysation injection. However, that amount was enough to induce estradiol synthesis in the ovary, and the plasma profiles of that hormone were similar after both treatments (pituitary extract or LH-RH injection) : between 5 and 7 hrs after the c-GTH level increased, the plasma $E_{2}$ rose. On the other hand, the higher $17 \beta-E_{2}$ level 12 hrs after hypophysation (as compared to the LH-RH treatment) might be related to the higher c-GTH level.

Reçu en septembre 1979. Accepté en février 1980.

Acknowledgements. - We wish to thank Miss Aline Solari for help with the statistical analysis and Ms. Alice Daifuku for reading the English manuscript.

Résumé. Les teneurs plasmatiques en hormone gonadotrope (GTH) et en œstradiol $17 \beta\left(E_{2}-17 \beta\right)$ ainsi que le stade des ovocytes ont été étudiés chez la Carpe commune Cyprinus carpio L., après « hypophysation 》 classique ( 2 injections intrapéritonéales d'hypophyses, $0,3 \mathrm{mg} / \mathrm{kg}$ et $2,7 \mathrm{mg} / \mathrm{kg}$ à $12 \mathrm{~h}$ d'intervalle) ou traitement au LH-RH (2 injections intracardiaques de $3 \mu \mathrm{g} / \mathrm{kg}$ à $3 \mathrm{~h}$ d'intervalle). Après la première injection d'hypophyses ou le traitement au LH-RH, on observe une augmentation de la GTH plasmatique suivie de celle de $l^{\prime} E_{2}-17 \beta, 7 \mathrm{~h}$ après l'injection. La teneur élevée en GTH provoquée par la deuxième injection d'hypophyses n'entraîne pas une sécrétion accrue de l' $E_{2}-17 \beta$.

Après « l'hypophysation » classique, la moitié des femelles ont ovulé mais leur caractéristique hormonale ne diffère pas significativement de celles qui n'ont pas ovulé.

Le traitement au LH-RH a provoqué uniquement la migration du noyau à la périphérie de l'ovocyte.

\section{References}

AIDA K., IZUMO R. S., SATOH H., HIBIYA T., 1978. Induction of ovulation in plaice and goby with synthetic LH releasing hormone. Bull. jap. Soc. Sci. Fish., 44, 445-450.

ANTALFI A., TÖLG E., 1975. Reproduction des carpes herbivores, traitement des larves et des alevins. Workshop on controlled reproduction of cultivated fishes. F.A.O., Rome 1975. EIFAC technic. Paper n: 25.

BIENIARZ K., EPLER P., LUONG-NGOC-THUY, BRETON B., 1980. Changes in blood gonadotropin level in mature female carp following hypophysial homogenate injections. Aquoculture (under publication).

BILLARD R., BRETON B., FOSTIER A., JALABERT B., WELL C., 1978. Endocrine control of the teleost reproductive cycle and its relation to external factors: Salmonid and cyprinid models, 37-38. In GAILLARD P. J., BOER H. H., Comparative Endocrinology, Biomed. Press, ElsevierNorth Holland, Amsterdam.

BRETON B., WEIL C., 1973. Effets du LH/FSH-RH synthétique et d'extraits hypothalamiques de carpe sur la secrétion d'hormone gonadotrope in vivo chez la carpe Cyprinus carpio. C. $R$. Acad. Sci. Paris, sér. D, 277, 2061-2064. 
BRETON B., KANN G., BURZAWA-GÉRARD E., 1971. Dosage radioimmunologique d'une hormone gonadotrope de carpe (Cyprinus carpio L.). C. R. Acad. Sci. Paris, sér. D, 272, 1515-1517.

CALLARD I. P. ,LANCE V., 1977. The control of reptilian follicular cycles reproduction and evolution. 4th inter. Symp. Comp. Biol. Reprod., Austr. Acad. Sci.

CONFERENCE ON APPLICATION OF HORMONES TO ECONOMIC FISH, 1975. Experiments on inducement of spawning in domestic fish by injection of synthesized hypothalamic luteinizing hormone-releasing hormone (LH-RH). Transl. from Chinese Xerue Tong-bao, 20, 43-48. Transl. ser. no 4186 FMS.

CHAN K. K. S., 1977. Effect of synthetic luteinizing hormone-releasing hormone (LH-RH) on ovarian development in Japanese medaka, Oryzias latipes. Can. J. Zool., 55, 155-160.

CRIM L. W., CLUETT D. M., 1974. Elevation of plasma gonadotropin concentration in response to mammalian gonadotropin releasing hormone (G-RH) treatment of the male brown trout as determined by radioimmunoassay. Endocr. Res. Commun., 1, 101-110.

CRIM L. W., PETER, R. E., BILLARD R., 1976. Stimulation of gonadotropin secretion by intraventricular injection of hypothalamic extracts in the goldfish. Gen. comp. Endocrinol., 30, 77-82.

DRAY F., TERQUI M., DESFOSSES B., CHAUFFOURNIER J. M., MOWSZOWICZ I., KHAN D., ROMBAUTS P., JAYLE M. F., 1971. Propriétés d'immunsérums anti-17ß oestradiol obtenus chez différentes espèces animales avec l'antigène 17ß-oestradiol-6-0 carboxyméthoxine serum-albumine de bœuf. C. R. Acad. Sci. Paris, sér. D, 277, 2280-2283.

ELEFTHERIOU B. E., NORMAN R. L., SUMMERFELT R., 1968. Plasma levels of 1,3,5,-(10)-estratriene-3,17 $\beta$ diol and 3,17 $\Delta$-dihydroxy 1,3,5,(10)-estratriene-16-one in the carp. Steroids, 11, 89-92.

FOSTIER A., BRETON B., JALABERT B., 1979. Stimulation hypophysaire de la sécrétion oestradiol$17 \beta$ chez la Carpe commune Cyprinus carpio L. Ann. Endocrinol., 40, 83-84.

FOSTIER A., WEIL C., TERQUI M., BRETON B., JALABERT B., 1978. Plasma estradiol-17 $\beta$ and gonadotropin during ovulation in rainbow trout (Salmo gairdneri R.). Ann. Biol. anim. Bioch. Biophys., 18, 929-936.

HIROSE K., ISHIDA R., 1974. Induction of ovulation in the ayu (Plecoglossus altivelis) with LH-releasing hormone (LH-RH). Bull. jap. Soc. Sci. Fish., 40, 1235-1240.

HORVATH L., POTECZINE E., FEHER G. K., FEHER T., 1978. Isolation and quantitative determination of sex hormones in carp (Cyprinus carpio L.). Acta biol. Acad. Sci. hung., 29, 23-27.

JALABERT B., 1975. Modulation par différents stéroïdes non maturants de l'efficacité de la $17 \alpha-$ hydroxy-20ß-dihydroprogestérone ou d'un extrait gonadotrope sur la maturation intrafolliculaire in vitro des ovocytes de truite Arc-en-ciel Salmo gairdneri. C. R. Acad. Sci. Paris, sér. D, 281, 811-814.

JALABERT B., BRETON B., BRZUSKA E., FOSTIER A., WIENIAWSKI J., 1977. A new fool for induced

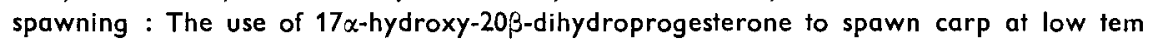
perature. Aquaculture, 10, 353-364.

KATZ Y., ECKSTEIN B., 1974. Changes in steroid concentration in blood of female Tilapia aurea (Teleostei, Cichlidae) during initiation of spawning. Endocrinology, 95, 963-967.

LAM T. J., PANDEY S., HOAR W. S., 1975. Induction of ovulation in goldfish by synthetic luteinizing hormone-releasing hormone (LH-RH), Can. J. Zool., 53, 1189-1192.

LAM T. J., PANDEY S., NAGAHAMA Y., HOAR W. S., 1976. Effect of synthetic luteinizing hormonereleasing hormone (LH-RH) on ovulation and pituitary cytology of the goldfish Carassius ouratus. Can. J. Zool., 54, 816-824.

SCHRECK C. B., HOPWOOD M. L., 1974. Seasonal androgen and estrogen patterns in the goldfish, Carassius auratus. Trans. am. Fish. Soc., 103, 375-378.

SOKOLOWSKA M., POPEK W., BIENIARZ K., 1978. Synthetic releasing hormones LH/FSH-RH and LH-RH : Effect of intracerebral and intramuscular injections on female carp (Cyprinus carpio L.). Ann. Biol. anim. Bioch. Biophys., 18, 963-967.

STACEY N., E., COOK A. F., PETER R. E., 1979. Ovulatory surge of gonadotropin in the goldfish, Carassius auratus. Gen. comp. Endocrinol., 37, 246-249.

STERLING R. J., LEA R., SHARP R., 1978. The stimulation of androgen secretion by luteinizing hormone-releasing hormone in the cockerel. IRCS, 6, 531.

SUMPTER J. P., JENKINS N., DODD J. M., 1978. Hormonal control of steroidogenesis in an elasmobranch fish (Scyliorhinus canicula L.). J. Endocrinol., 79,28-30P. 
THE FISH REPRODUCTIVE PHYSIOLOGY RESEARCH GROUP, AMOY FISHERIES COLLEGE, THE PEPTIDE HORMONE GROUP FROM SHANGAI, 1978. Radioimmunoassay on serum gonadotropin of carp, Cyprinus carpio L. Acta bioch. bioph. sin., 10, 399-407.

VAN BOHEMEN C. G., LAMBERT J. G. D., 1979. Steroidogenesis in the ovary of the rainbow trout, Salmo gairdneri. J. Endocrinol., 80, 37-38.

WEIL C., BRETON B., REINAUD P. 1975. Ełude de la réponse hypophysaire à l'administration de Gn-RH exogène au cours du cycle reproducteur annuel chez la carpe Cyprinus carpio L. C. R. Acad. Sci. Paris, sér. D, 280, 2469-2472.

WEIL C., BILLARD R., BRETON B., JALABERT B., 1978. Pituitary response to LH-RH at different stages of gametogenesis in the rainbow trout (Salmo gairdneri). Ann. Biol. anim. Bioch. Biophys., 18, 863-869. 